\title{
The impact of a vehicle braking system state on safe driving - part one
}

Piotr Aleksandrowicz ${ }^{1, *}$

${ }^{1}$ Machine Maintenance Department, Institute of Machinery Operation and Transport, University of Science and Technology, Al. prof. S. Kaliskiego 7, 85-796, Bydgoszcz, Poland

\begin{abstract}
The state of a vehicle braking system is one of the key factors determining the safety of the driver, passengers and other road users. During operation of a vehicle, the elements of its braking system undergo the process of wear and they are exposed to damage. Deterioration of the braking system efficiency has a direct impact on the collision speed. Thus, diagnosing a braking system during a vehicle operation is of key importance. Therefore, the authors of this article have undertaken the task to identify the influence of the state of a braking system particular element on the collision speed and kinetic energy of the impact. The obtained results of simulation calculations have proven a significant role of a braking system diagnosing in elimination of vehicles whose braking systems do not function properly as using inefficient brakes poses a significant threat to road traffic users and vehicles.
\end{abstract}

\section{Introduction}

Road traffic involves a risk of accidents, collisions and vehicle failures. For example, work [1] deals with the risk of failure and the impact of prevention repairs on the risk reduction. However, elements and systems of a vehicle undergo natural wear affecting the quality of transport processes, which is described in works [2,3]. An increase in transport volume and people's mobility increases these phenomena. The number of cars in Poland is constantly growing. In 2017, the number of registered motor vehicles was 29149 178. As many 32760 accidents were reported to the police, in which 2831 people were killed and 39466 were injured. Whereas, 436469 collisions were reported to the police. No significant improvement for neither of these categories had been reported until 2016 (http://statystyka.policja.pl).

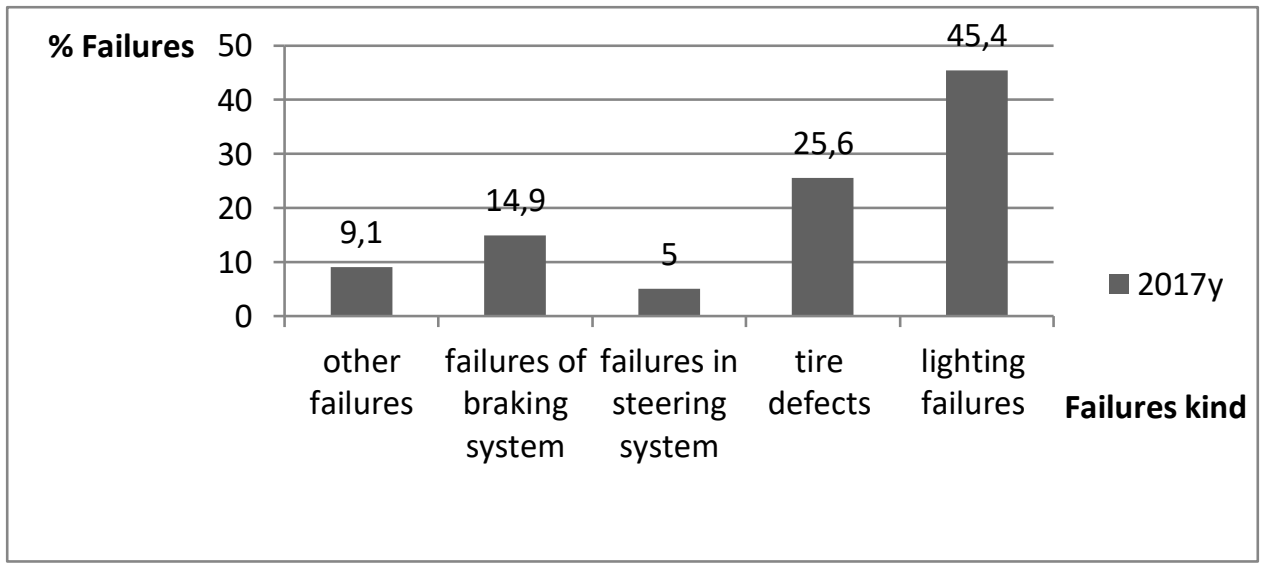

Fig. 1. Kinds of failures found in vehicles involved in road accidents in 2017.

\footnotetext{
*Corresponding author: paleksandrowicz@utp.edu.pl
} 
The main cause of road accidents is improper behavior of road users, though some accidents are caused by poor technical condition of a vehicle. Failures which were found in post-accident vehicle technical state diagnosing included lighting, tires and braking system. They account for $14.9 \%$ of all the failures found in the diagnosed vehicles.

Below, there are kinds of failures reported for vehicles which were involved in accidents in 2017 (http://statystyka.policja.pl).

The possibility to reduce speed at any time of driving or pull up the vehicle, regardless of the weather conditions and time of operation, is the key factor of road traffic safety. Especially that, dangerous situations involve the necessity to brake immediately. To perform this task, a driver needs to use the vehicle braking system. Thus, a braking system belongs to the most important structural systems of a vehicle and, therefore, it needs to meet several requirements. The most important ones were formulated in regulations R13 or R13-H ECE as well as in the EU directive 98/12/WE [4].

\section{Braking system of a vehicle}

The process of braking involves changing the vehicle kinetic energy into, most frequently, heat and it is advisable to increase the motion resistance. Once the driver starts pulling up the braking force, acting at the contact of the vehicle wheels with the road surface, reduces its speed. Currently, vehicles are equipped with hydraulic braking systems. In this type of systems, transmission of braking force is performed by means of a braking fluid.

\subsection{Design of two-circuit braking system}

Fig. 2 shows a scheme of a typical two circuit disc braking system. Such a system includes: braking pump (1), correctors of braking force distribution (2), supporting device (3) brake pedal (4), front wheel brake (5) rear wheel brake (6) (http://zssplus.pl/publikacje/publikacje45.htm).

However, Fig. 3 shows a scheme of a disc brake with two expanders in Dunlop system. This kind of braking system includes: expander (1), brake disc (2), brake pads 3 and 4), body of clamp (5) sealing ring (6) (http://zssplus.pl/publikacje/publikacje45.htm).

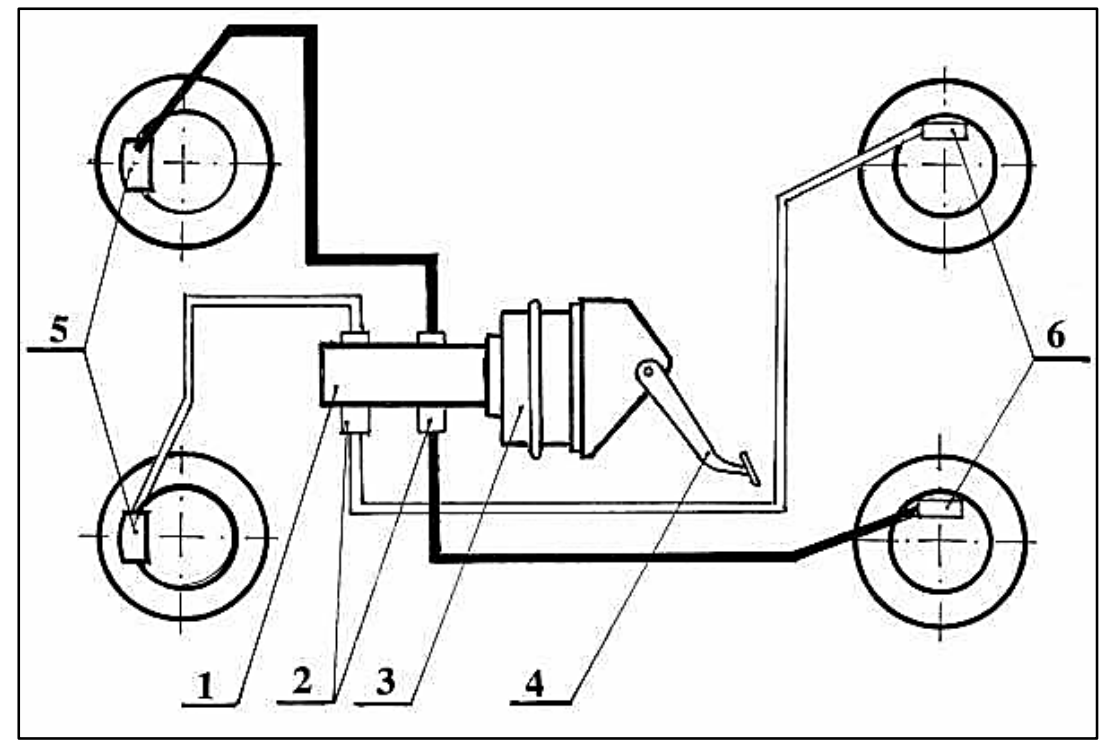

Fig. 2. Scheme of a two two-circuit disc braking system. 


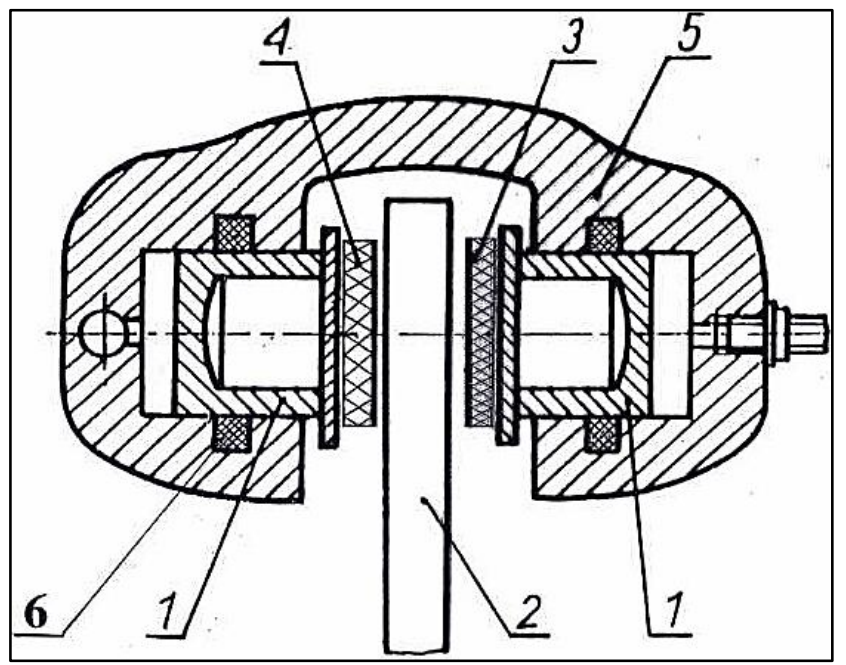

Fig. 3. Scheme of brake with two expanders (system Dunlop).

\subsection{Design requirements for braking systems}

The major design requirements for braking systems are supposed to provide the possibility of [5]:

$>$ blocking the vehicle wheels upon pressing the brake pedal $490 \mathrm{~N}$, on dry asphalt (surface with adhesion coefficient, at least $\mu=0.7$ ),

$>$ stroke of the brake pedal from the initial position to wheel blockage, not be higher than $130 \mathrm{~mm}$,

$>$ uniform increase of braking force and its proportionality to the brake pedal pressure,

$>$ uniform distribution of braking force onto the left and the right wheels of the vehicle according to established proportionality of braking force of the front axle wheels,

$>$ possibility of operation with multiple use in short periods of time, regardless of atmospheric conditions,

$>$ durability,

$>$ long periods between necessary regulations.

\subsection{Forces acting on the vehicle while braking}

In order to establish obtainable braking delay, the force system basic conditions are used, which are presented in Fig. 4.

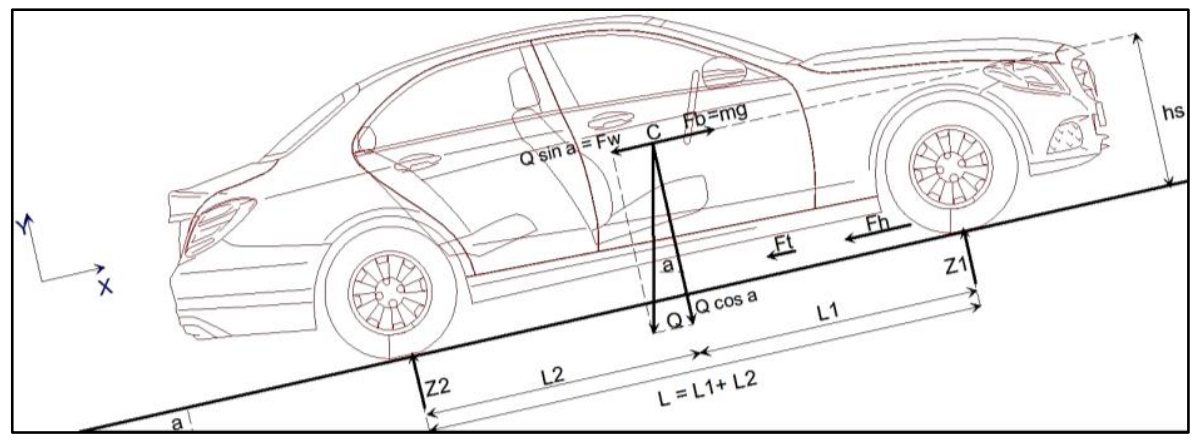

Fig. 4. System of forces acting on the vehicle while braking.

Conditions of forces balance can be expressed by formulas:

$$
F_{\mathrm{h}}-\mathrm{F}_{\mathrm{b}}+F_{\mathrm{t}}+F_{\mathrm{w}}=0
$$




$$
Z_{1} L_{1}-F_{\mathrm{b}} h_{\mathrm{s}}+h_{\mathrm{s}} Q \sin \alpha-L_{2} Q \cos \alpha=0
$$

where:

$F_{\mathrm{b}}$ - inertia force,

$F_{\mathrm{h}}-$ braking force,

$\alpha$ - elevation angle,

$F_{\mathrm{t}}$ - rolling resistance force,

$F_{\mathrm{w}}$ - elevation reistance force,

$h_{\mathrm{s}}$ - height of mass center location,

$\mathrm{Z}_{1}$ and $\mathrm{Z}_{2}$ - wheel reaction normal forces,

$L_{1}$ and $L_{2}$ - distance of the mass center from the wheel axle,

$Q=\mathrm{m} \cdot \mathrm{g}-\mathrm{m}$ - vehicle curb weight, $\mathrm{g}$ - acceleration of gravity.

\section{Parameters the research object and the movement environment}

The research object is a passenger vehicle Mercedes class C type W205. The most important technical data of the vehicle and parameters of the movement environment accepted for simulation calculations are presented in table 1.

Table 1. Technical data of the object of the research and parameters of the movement environment.

\begin{tabular}{|c|c|}
\hline Parameter & Value \\
\hline Vehicle curb weight & $1430 \mathrm{~kg}$ \\
\hline Driver mass & $68 \mathrm{~kg}$ \\
\hline $\begin{array}{c}\text { Length/Width/ } \\
\text { Height of vehicle }\end{array}$ & $4.69 \mathrm{~m} / 1.81 \mathrm{~m} / 1.44 \mathrm{~m}$ \\
\hline Wheel base 1-2 & $2.84 \mathrm{~m}$ \\
\hline $\begin{array}{c}\text { Braking efficiency of } \\
\text { vehicle }\end{array}$ & $10.2 \mathrm{kN}$ \\
\hline ABS & Yes \\
\hline Size of vehicle tires & $205 / 60 \mathrm{R} 16$ \\
\hline $\begin{array}{c}\text { Dry asphalt road } \\
\text { adhesive friction } \mu_{l}=0.8 \\
\text { slip friction } \mu_{2}=0.75\end{array}$ \\
\hline $\begin{array}{c}\text { Rolling resistance } \\
\text { coefficient }\end{array}$ & 0.015 \\
\hline Road inclination & $\alpha=2 \circ$ \\
\hline
\end{tabular}

\section{Case study - own research}

Using data from works $[4,5]$ the friction coefficient of usable brake pads was accepted to be 0.38 for simulation calculations (Fig. 4a), whereas, for totally worn brake pads it was 0.24 (Fig. 4b) which being converted into the braking system efficiency, were, respectively, 100 $\%$ and $63 \%$. For simulation, the vehicle initial speed was $25 \mathrm{~m} \cdot \mathrm{s}^{-1}$. Simulation calculations were performed with the use of V-SIM4 code. This program is used in reconstruction of road accidents, but it is also applied for verification of damage by SDC method, which is described in work $[6,7]$ and for calculation of the impact parameters identified from the crash a test [8]. The obtained calculation results are shown in Fig. 5a-j and an video (https://youtu.be/rxxkmEsE6O8). 


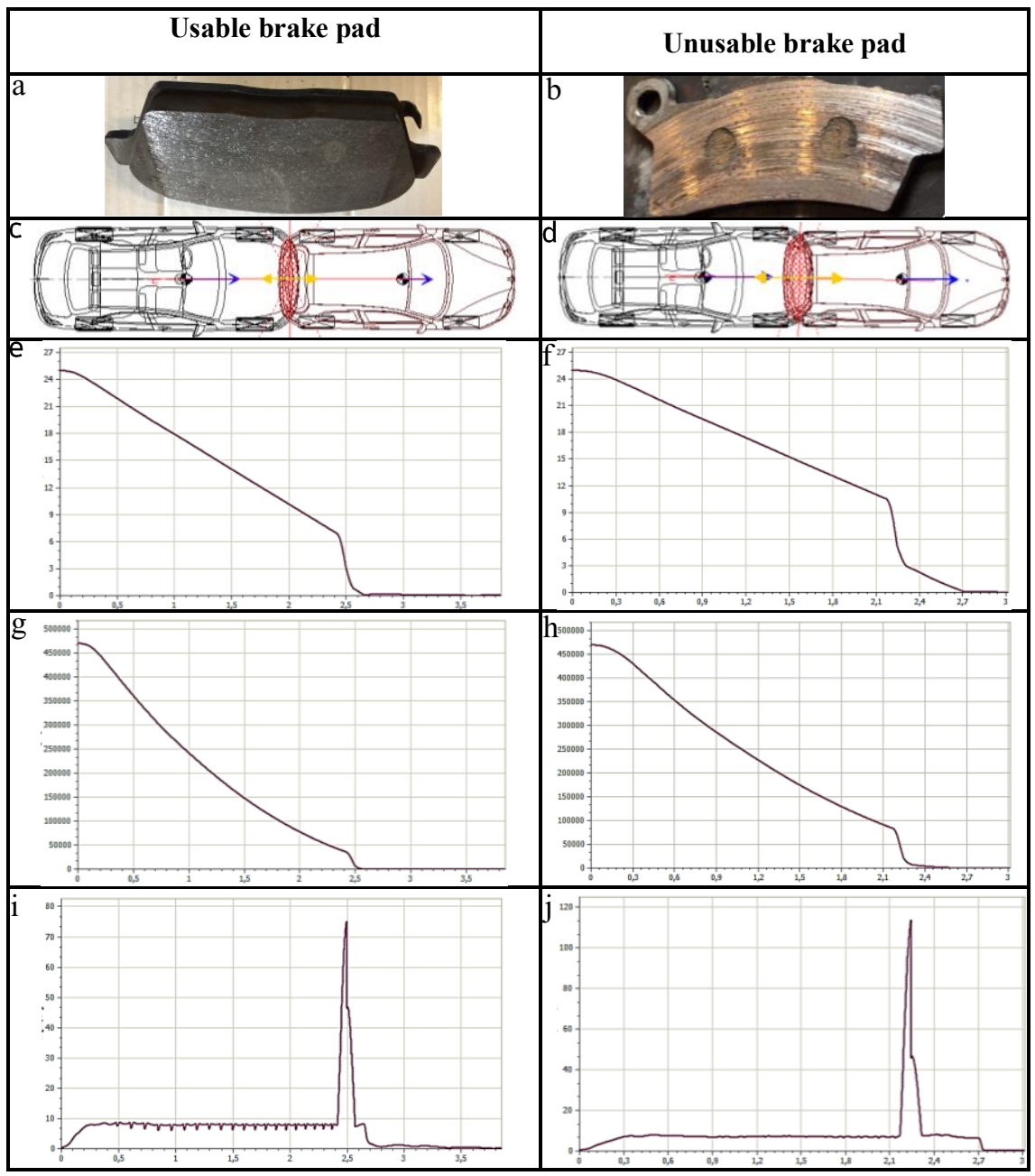

Fig. 5. Usable (a) and unusable brake pads (b), depth of car body deformation for usable (c) and unusable brake pads (d), impact speeds for usable (e) and unusable brake pads (f), kinetic energy of vehicle impact for usable $(\mathrm{g})$ and unusable brake pads $(\mathrm{h})$, delay of vehicle braking for usable (i) and unusable brake pads (j).

\section{Conclusions}

Simulation calculations have shown that worn out brake pads have an influence on:

$>$ impact with collision speed higher than $3.6 \mathrm{~m} \cdot \mathrm{s}^{-1}$,

$>$ increase in depth of car bodies penetration during impact by $0.20 \mathrm{~m}$,

$>$ impact with kinetic energy higher by $47195 \mathrm{~kJ}$,

$>$ decrease in delay resulting in prolongation of the braking distance by $1.8 \mathrm{~m}$.

The obtained results show the importance of brake pads diagnosing to eliminate from operation vehicles whose friction elements of braking system indicate limit wear or close to limit wear.

\section{References}


1. L. Knopik, K. Migawa. Optimal age-replacement policy for non-repairable technical objects with warranty. Eksploatacja i Niezawodność - Maintenance and Reliability, vol. 19, no. 2, pp. $172-178,(2017)$

2. Ł, Muślewski. Evaluation Method of Transportation Systems Operation Quality. Polish Journal of Environmental Studies. vol. 18, No. 2A, Hard Olsztyn, (2009)

3. Ł. Muślewski, M.Woropay. Theoretical grounds to evaluate of the transport system operation. Maritime Transportation and Exploitation of Ocean and Coastal Resources GuedesSoares, Garbatov\& Fonseca, Taylor \& Francis Group, London (2005)

4. J. Wicher. Motor vehicles and road traffic safety. WKŁ Warsaw. pp. 126-127, (2012)

5. H. Tylicki, B. Żółtowski. Terra- Technology Operation and Maintenance of Selected Systems of Vehicles. University Publisher PWSZ, Piła, pp. 80 (2005)

6. P. Aleksandrowicz. Analysis of vehicle collisions with the SDC method. $23^{\text {rd }}$ International Conference Engineering Mechanics, 15-18.05.2017 Svratka, Czech Republic, pp. 78-81, (2017)

7. P. Aleksandrowicz. Verification of airbag activation during collision of vehicles with the use of SDC method. 24 ${ }^{\text {th }}$ International Conference Engineering Mechanics, 14-17.05.2018 Svratka, Czech Republic, pp. 17-20, (2018)

8. R. Kostek, P. Aleksandrowicz. Effect of contact parameters on the pattern of vehicle collisions with a round pillar. $23^{\text {rd }}$ International Conference Engineering Mechanics, 15 18.05.2017 Svratka, Czech Republic, pp. 490-493, (2017) 